\title{
3. PETROLOGY OF CHILLED DIKE MARGINS RECOVERED FROM HOLE 504B, LEG $140^{1}$
}

\author{
A.W. McNeill ${ }^{2}$
}

\begin{abstract}
Mineral and whole-rock geochemical data are presented for chilled dike margins from the lower sheeted dike complex of Deep Sea Drilling Project/Ocean Drilling Program (DSDP/ODP) Hole 504B. Compositions of phenocrystic plagioclase $\left(\mathrm{An}_{80-89}\right)$; olivine ( $\left.\mathrm{Fo}_{82-86}\right)$; clinopyroxene $\left(\mathrm{Wo}_{52} \mathrm{En}_{40} \mathrm{Fs}_{8}\right.$, with $\mathrm{Cr}_{2} \mathrm{O}_{3}$ up to $\left.1.2 \%\right)$; and rare chromian spinel $(\mathrm{Cr} \# 43)$ are consistent with those from the lavas and the upper dike complex recovered previously (DSDP Legs 69, 70,83, and ODPLeg 111). Major and trace element compositions fall in group $\mathrm{D}$ of Autio and Rhodes (1983) and have high $\mathrm{CaO} / \mathrm{Na}_{2} \mathrm{O}$, and low $\mathrm{TiO}_{2}, \mathrm{~K}_{2} \mathrm{O}$, and $(\mathrm{La} / \mathrm{Sm})_{\mathrm{N}}$ values consistent with previous analyses from this site.
\end{abstract}

\section{INTRODUCTION}

Hole 504B, situated on 5.9-m.y.-old crust formed at the intermediate spreading-rate Costa Rica Rift, is currently the longest drilled section of in-situ oceanic crust and represents confirmation for the ophiolitic model of oceanic crust. Leg 140, the seventh Ocean Drilling Program/Deep Sea Drilling Project (ODP/DSDP) leg to occupy Hole 504B, deepened the hole to 2000.4 meters below sea floor (mbsf) (1725.9 m into basement) and is interpreted to have penetrated the lower part of the sheeted dike complex (i.e., seismic Layer 2C; Shipboard Scientific Party, 1992).

The purpose of this contribution is to document variations in the mineralogy and bulk geochemistry of chilled dike margins recovered during Leg 140 for comparison with the previously cored sheeted dikes and extrusive sequence.

\section{METHODS}

Analyses were completed on polished thin sections prepared both aboard ship and at the University of Tasmania, Australia. Mineral analyses were completed on a Cameca SX-50 microprobe using a WDS system and Cameca PAP data reduction routines. Analytical conditions are listed in Table 1.

Splits of shipboard geochemical samples, and an additional sample, 140-504B-203R-1,33-36 cm, were analyzed for major elements by X-ray fluorescence on a Phillips PW-1480, at the University of Tasmania, using methods outlined by Norrish and Chappell (1977). Loss on ignition analyses were carried out overnight at $1050^{\circ} \mathrm{C}$ on 0.9-1.1 g samples. Results of analyses of two standards are included in Sparks and Zuleger (this volume). Rare-earth elements (REE), Hf, $\mathrm{Cs}, \mathrm{Sc}, \mathrm{Th}$, and $\mathrm{Cr}$ were determined by instrumental neutron activation on 0.8-1.1 g samples at Becquerel Laboratories, Sydney, Australia.

\section{RESULTS}

\section{Gross Characteristics}

The downhole distribution of chilled margins recovered during Leg 140 is shown on Figure 1, and samples used in this study are listed in Table 2. Due to poor core recovery, averaging $12.6 \%$ overall and $<6 \%$ in fine-grained and chilled lithologies, contacts between dikes were not recovered in many cases; however, aphyric micro and cryptocrystalline lithologies often containing quench crystals indicate proximity to dike margins where the contact is missing. All the chilled

\footnotetext{
${ }^{1}$ Erzinger, J., Becker, K., Dick, H.J.B., and Stokking, L.B. (Eds.), 1995. Proc. ODP, Sci. Results, 137/140: College Station, TX (Ocean Drilling Program).

${ }^{2}$ Geology Department, University of Tasmania, Hobart, 7001, Tasmania, Australia.
}

margins recovered host phenocrysts, with abundances ranging from aphyric ( $<1 \%$ phenocrysts) to moderately phyric $(2 \%-10 \%$ phenocrysts), and are subdivided on the basis of phenocryst assemblage into plagioclase $(\mathrm{P})$, plagioclase + clinopyroxene $(\mathrm{PC})$, and plagioclase + clinopyroxene + olivine $(\mathrm{PCO})$ types $($ Table 1$)$. Two microdikes $(<1$ $\mathrm{cm}$ thick) are interpreted to be apophyses from chilled margins. In both samples the microdikes terminate in filled fractures.

Chilled margins have variable morphology from planar to convolute and brecciated, but are dominantly planar, on the scale of observation available in drill core. Structurally re-oriented chilled margins are all steeply dipping $\left(79^{\circ}-85^{\circ}\right)$, consistent with dips recorded on Leg 111 (Shipboard Scientific Party, 1988) but steeper than those recovered on Leg 83 ( $50^{\circ}$ to near vertical; Adamson, 1985). The majority of samples are composed of one contact between chilled material and fine to medium-grained diabase; however, Sample 140504B-219R-1, 6-12 cm, has two chilled margins, one plagioclaseand the other plagioclase-clinopyroxene-phyric, separated by a thin band of strongly altered and veined diabase. Similar contact relations have been described by Kempton (1985).

No glass was seen in groundmass of the chilled margins, but a wide range of quench textures similar to those described by Kempton (1985) is developed, from cryptocrystalline equigranular (designated by Kempton as Zone 2 and $2 \mathrm{~A}$ ) adjacent to contacts, to microcrystalline intergrown tabular plagioclase and clinopyroxene having interstitial bowtie-spherulitic material (equivalent to Kempton's Zone 6). Mineralogically the groundmass is dominated by clinopyroxene and plagioclase with skeletal to anhedral FeTi-oxides and sulfides. No fresh olivine was recognized.

\section{Petrography and Mineral Chemistry}

\section{Olivine}

Olivine is present in the phenocryst assemblage of two samples (Table 2); however, in only one of these, 140-504B-222R-1, 0-4 cm, are fresh phenocrysts preserved. Olivine has a bimodal size distribution; large euhedral to subhedral and occasionally embayed grains of $0.4-4 \mathrm{~mm}$ (generally $<1.2 \mathrm{~mm}$ ) diameter, and euhedral to subhedral microphenocrysts of $0.03-0.12 \mathrm{~mm}$ diameter.

Olivine phenocrysts may host inclusions of plagioclase and microcrystalline material and may form glomerocrysts with plagioclase. Only one phenocryst was fresh enough for analysis (Table 3 ) and is unzoned, having a composition of $\mathrm{Fo}_{85.8}$. Microphenocrysts are variably altered, often with fresh cores, and lack inclusions. Compositions of microphenocrysts range from $\mathrm{Fo}_{83.1}$ to $\mathrm{Fo}_{85.2}$ (Table 3).

Compositions of both phenocrysts and microphenocrysts are consistent with analyses from the sheeted dikes of Leg 111 (Shipboard Scientific Party, 1988) and Leg 83 (Kempton et al., 1985) and similar 

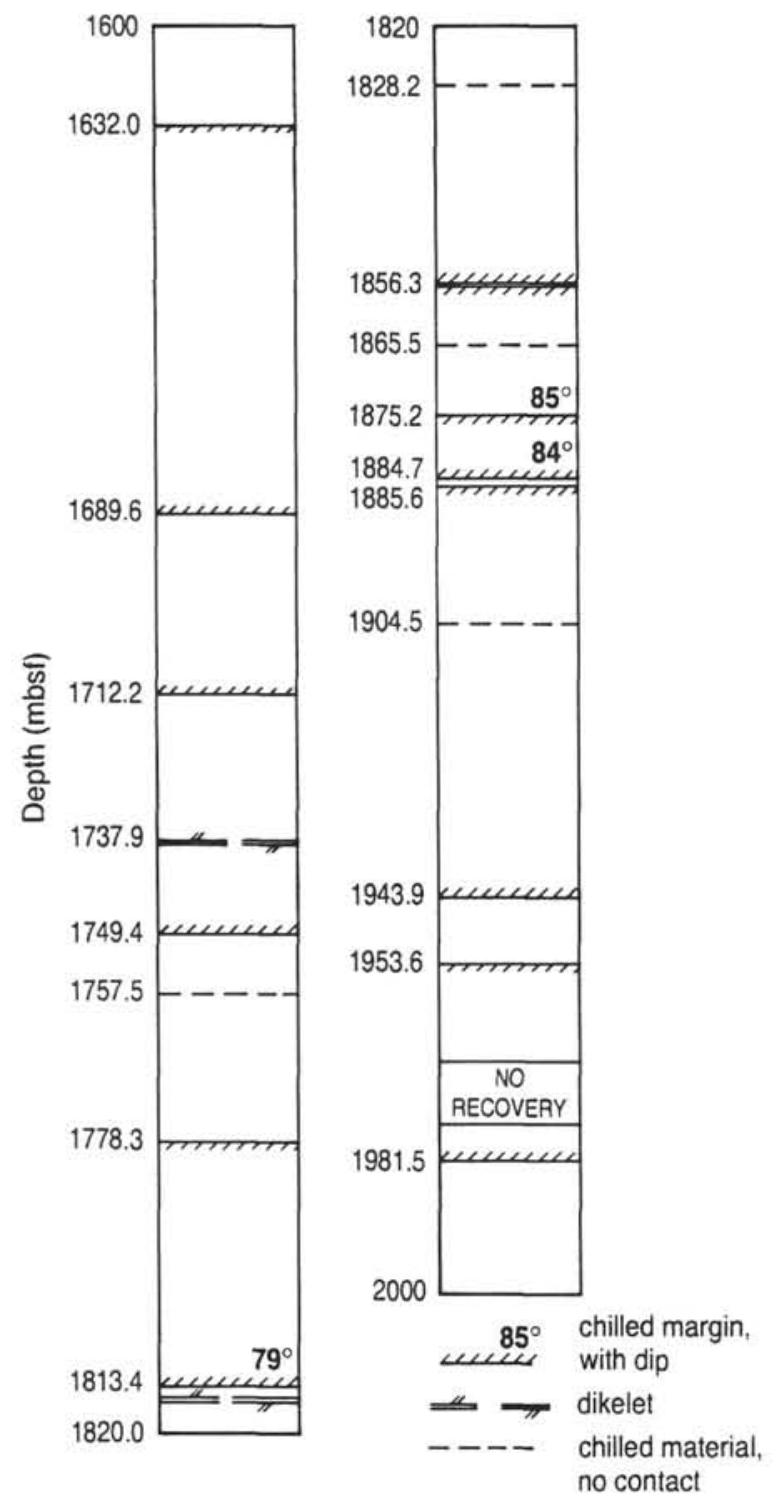

Figure 1. Downhole distribution of chilled margins recovered from Hole 504B, Leg 140. Orientation of ticks on chilled margin symbol indicates interpreted direction of chilling, either up-, or downhole.

to the less magnesian olivines of the pillow lava sequence (Natland et al., 1983). Olivines of $\mathrm{Fo}_{86-88.7}$ from Unit 227, Leg 140 Cores 199 and 200, (C. Laverne, pers. comm., 1993) are associated with higher bulk rock $\mathrm{Mg \#} \mathrm{(66-69),} \mathrm{and} \mathrm{are} \mathrm{compositionally} \mathrm{similar} \mathrm{to} \mathrm{the} \mathrm{magnesian}$ olivines in the pillow lavas (Natland et al., 1983).

Fe-Mg partitioning between olivine and melt is well constrained, with $\mathrm{a} \mathrm{K}_{\mathrm{d}}$ of approximately 0.3 , for pressures $<10 \mathrm{Kbar}$ (Roeder and Emslie, 1970; Ulmer, 1989). Using this $\mathrm{K}_{d}$ the microphenocrysts are in equilibrium with the bulk rock composition of this sample $\left(\mathrm{Mg} \#_{\text {calc }}\right.$ $=59.6-63.4, \mathrm{Mg}_{\text {bulk }}=63$ ). The phenocryst yields slightly higher liquid Mg\# (63-64), but both results are interpreted as indicating the olivines were in equilibrium with the bulk rock.

\section{Spinel}

Spinel is extremely rare in the samples examined. Only one redbrown subhedral spinel inclusion in plagioclase, from Sample 140504B-222R-1, 0-4 cm, was analyzed. An Mg\# of 66.2 and Cr\# of 43 are consistent with analyses from Natland et al. (1983) and Kempton et al. (1985). The scarcity and mode of occurrence of spinel in the
Table 1. Electron microprobe experimental conditions.

\begin{tabular}{lcc}
\hline & \multicolumn{3}{c}{ Plagioclase } & Olivine/pyroxene \\
\hline Voltage (kV) & 15 & 15 \\
Current (nA) & 10 & 20 \\
Count times (peak/background; & seconds) \\
$\mathrm{Si}$ & $10 / 5$ & $10 / 5$ \\
$\mathrm{Ti}$ & $20 / 10$ & $20 / 10$ \\
$\mathrm{Al}$ & $10 / 5$ & $10 / 5$ \\
$\mathrm{Fe}$ & $30 / 15$ & $20 / 10$ \\
$\mathrm{Mg}$ & $30 / 15$ & $10 / 5$ \\
$\mathrm{Mn}$ & $20 / 10$ & $20 / 10$ \\
$\mathrm{Ca}$ & $10 / 5$ & $10 / 5$ \\
$\mathrm{Na}$ & $20 / 10$ & $20 / 10$ \\
$\mathrm{~K}$ & $20 / 10$ & $20 / 10$ \\
$\mathrm{Cr}$ & $20 / 10$ & $20 / 10$ \\
$\mathrm{Ni}$ & $\mathrm{n} / \mathrm{a}$ & $20 / 10$ \\
$\mathrm{Sr}$ & $20 / 10$ & $\mathrm{n} / \mathrm{a}$ \\
$\mathrm{Ba}$ & $20 / 10$ & $n / a$ \\
\hline
\end{tabular}

Note: $\mathrm{n} / \mathrm{a}=$ element not analyzed.

chilled margins are in contrast to the extrusive sequence where spinel occurs both as inclusions in phenocrysts and as euhedral microphenocrysts, but only when clinopyroxene is absent as a phenocryst phase (Natland et al., 1983). One possible explanation is that the resorption of clinopyroxene phenocrysts during ascent of the magma and dike emplacement results in the release of $\mathrm{Cr}$ and crystallization of spinel in the pillow lavas (Shipboard Scientific Party, 1992).

\section{Clinopyroxene}

Clinopyroxene in the PCO assemblage chilled margins (Table 4) occurs both as megacrysts and phenocrysts, up to $2.8 \mathrm{~mm}$ in length, and microphenocrysts (rare in Sample 140-504B-222R-1, 0-4 cm), up to $0.18 \mathrm{~mm}$ in length. Although maximum and minimum size ranges overlap, these two types are morphologically distinct; megacrysts and phenocrysts (hereafter referred to as phenocrysts, as chemically they are indistinguishable) range from euhedral to rounded anhedral having inclusions of plagioclase and cryptocrystalline material. Phenocrysts are commonly embayed and partially resorbed and may be twinned. Microphenocrysts are euhedral to subhedral, often with hollow (cryptocrystalline groundmass filled) terminations, and are untwinned. Clinopyroxene also occurs as subhedral to anhedral crystals in open spherulites with plagioclase. In the PC assemblage margins clinopyroxene is dominantly altered to amphibole and occurs both as microphenocrysts and in spherulites.

No low Ca pyroxenes were analyzed (Table 4) and compositions are those of magnesium-rich augite, using the classification of Morimoto et al. (1989). Phenocrysts have consistent Mg\# (85.3-87.4) cores and are largely unzoned to weakly normally or reversely zoned, similar to phenocrysts from the pillow lava sequence (Natland et al., 1983). The strong Mg\# zonation recorded from some phenocrysts in medium-grained rocks higher in the sheeted dikes is not evident (Kusakabe et al., 1989; Kempton et al., 1985). The phenocrysts are also $\mathrm{Cr}$-rich, up to $1.16 \% \mathrm{Cr}_{2} \mathrm{O}_{3}$ (Fig. 2) as has been recorded from higher in the section where they are described as megacrysts (Natland et al., 1983) or xenocrysts (Kempton et al., 1985). The trend of decreasing $\mathrm{Cr}$ with decreasing $\mathrm{Mg}$ \# in Figure 2 is the result of fractionation (Grove and Bryan, 1983). Differences between the abundance of $\mathrm{Cr}, \mathrm{Ti}$, and $\mathrm{Al}$ in phenocrysts and microphenocrysts/spherulites is likely to be the result of kinetic effects during quenching (Coish and Taylor, 1979; Gamble and Taylor, 1980). However, phenocrysts have higher Mg\#, and lower $\mathrm{TiO}_{2}$, and $\mathrm{Al}_{2} \mathrm{O}_{3},<0.35 \%$ and $<3.5 \%$, respectively, than microphenocrysts (Fig. 3).

\section{Plagioclase}

Plagioclase is the most abundant phenocryst phase in PCO assemblage chilled margins and forms a seriate porphyritic texture with 
Table 2. Samples from Leg 140, Hole 504B, used in this study.

\begin{tabular}{|ccccc}
\hline $\begin{array}{c}\text { Phenocryst assemblage } \\
\text { PCO }\end{array}$ & PC & P & Microdikes & $\begin{array}{l}\text { Chilled material } \\
\text { (no contact) }\end{array}$ \\
\hline $195 \mathrm{R}-1,7-10 \mathrm{~cm}$ & $219 \mathrm{R}-1,7-11 \mathrm{~cm}$ & $187 \mathrm{R}-1,11-15 \mathrm{~cm}$ & $201 \mathrm{R}-1,14-17 \mathrm{~cm}$ & $203 \mathrm{R}-1,4-7 \mathrm{~cm}$ \\
$222 \mathrm{R}-1,0-4 \mathrm{~cm}$ & $222 \mathrm{R}-1,76-79 \mathrm{~cm}$ & $203 \mathrm{R}-1,34-35 \mathrm{~cm}$ & $213 \mathrm{R}-1,32-34 \mathrm{~cm}$ & $213 \mathrm{R}-1,3-6 \mathrm{~cm}$ \\
& $222 \mathrm{R}-1,89-93 \mathrm{~cm}$ & $208 \mathrm{R}-1,30-33 \mathrm{~cm}$ & & $213 \mathrm{R}-1,26-28 \mathrm{~cm}$ \\
& & $213 \mathrm{R}-1,45-47 \mathrm{~cm}$ & & $216 \mathrm{R}-1,32-34 \mathrm{~cm}$ \\
& $219 \mathrm{R}-1,7-11 \mathrm{~cm}$ & & $220 \mathrm{R}-1,2-6 \mathrm{~cm}$ \\
& & $231 \mathrm{R}-1,4-5 \mathrm{~cm}$ & & $222 \mathrm{R}-1,100-100 \mathrm{~cm}$ \\
& & & $224 \mathrm{R}-1,76-78 \mathrm{~cm}$ \\
\hline
\end{tabular}

Notes: Phenocryst assemblage: $\mathrm{P}=$ plagioclase $\mathrm{C}=$ clinopyroxene; $\mathrm{O}=$ olivine.

Table 3. Representative olivine compositions, Sample 140-504B-222R-1, 0-4 cm.

\begin{tabular}{lrrrr}
\hline Analysis & \multicolumn{1}{c}{1} & \multicolumn{1}{c}{2} & \multicolumn{1}{c}{3} & \multicolumn{1}{c}{4} \\
\hline $\mathrm{SiO}_{2}$ & 39.52 & 40.05 & 39.82. & 39.94 \\
$\mathrm{TiO}_{2}$ & 0.00 & 0.03 & 0.00 & 0.00 \\
$\mathrm{Al}_{2} \mathrm{O}_{3}$ & 0.03 & 0.07 & 0.06 & 0.05 \\
$\mathrm{Cr}_{2} \mathrm{O}_{3}$ & 0.02 & 0.05 & 0.06 & 0.03 \\
$\mathrm{FeO}^{*}$ & 15.36 & 13.99 & 13.49 & 13.53 \\
$\mathrm{MnO}$ & 0.29 & 0.27 & 0.29 & 0.28 \\
$\mathrm{MgO}$ & 44.10 & 44.61 & 45.8 & 45.7 \\
$\mathrm{CaO}$ & 0.36 & 0.33 & 0.31 & 0.34 \\
$\mathrm{Na}{ }_{2} \mathrm{O}$ & 0.00 & 0.00 & 0.00 & 0.00 \\
$\mathrm{~K}_{2} \mathrm{O}$ & 0.02 & 0.01 & 0.00 & 0.00 \\
$\mathrm{NiO}$ & 0.23 & 0.23 & 0.14 & 0.15 \\
\hline Total & 99.93 & 99.64 & 99.97 & 100.02
\end{tabular}

Cations calculated on the basis of 4 oxygens

\begin{tabular}{lcccc}
$\mathrm{Si}$ & 0.997 & 1.005 & 0.995 & 0.997 \\
$\mathrm{Al}$ & 0.001 & 0.002 & 0.002 & 0.002 \\
$\mathrm{Fe}^{2+}$ & 0.324 & 0.294 & 0.282 & 0.283 \\
$\mathrm{Mg}$ & 1.659 & 1.670 & 1.706 & 1.701 \\
$\mathrm{Ca}$ & 0.010 & 0.009 & 0.008 & 0.009 \\
$\mathrm{Na}$ & 0.000 & 0.000 & 0.000 & 0.000 \\
$\mathrm{~K}$ & 0.001 & 0.000 & 0.000 & 0.000 \\
$\mathrm{Ti}$ & 0.000 & 0.001 & 0.000 & 0.000 \\
$\mathrm{Mn}$ & 0.006 & 0.006 & 0.006 & 0.006 \\
$\mathrm{Cr}$ & 0.000 & 0.001 & 0.001 & 0.001 \\
$\mathrm{Ni}$ & 0.005 & 0.005 & 0.003 & 0.003 \\
\cline { 2 - 5 } $\mathrm{Total}$ & 3.003 & 2.993 & 3.003 & 3.001 \\
$\mathrm{Mg} \#$ & 83.7 & 85.0 & 85.8 & 85.8 \\
\hline
\end{tabular}

Notes: Analyses: $1=0.06 \times 0.03 \mathrm{~mm}$ euhedral microphenocryst; $2=0.06 \times 0.05 \mathrm{~mm}$ euhedral microphenocryst, weakly altered rim; $3=$ core of euhedral $0.5 \times 0.3 \mathrm{~mm}$, partially altered phenocryst; 4 = rim of phenocryst in analysis 3. *All $\mathrm{Fe}$ as $\mathrm{FeO}$.

phenocrysts ranging in size from $3 \times 1.25 \mathrm{~mm}$ to $0.025 \times<0.005 \mathrm{~mm}$. These can be subdivided on the basis of morphology into phenocrysts and microphenocrysts/microlites. Phenocrysts are $>0.25 \times 0.07 \mathrm{~mm}$ in size, and are subhedral to anhedral. They may host inclusions of brown cryptocrystalline material, and very rare brown spinel. Rounded anhedral phenocrysts are rare and one occurrence has vermicular embayments around its margin. Plagioclase phenocrysts may also occur as inclusions in clinopyroxene and olivine, and form glomerocrysts of 3 to $>5$ crystals with other plagioclase, olivine or, rarely clinopyroxene phenocrysts.

Microphenocrysts and microlites occur as unincluded, single, skeletal to euhedral or subhedral laths often aligned with long axes parallel to the chilled contact. Plagioclase also occurs in a variety of spherulitic and variolitic clusters, with or without clinopyroxene, that are discussed below.

$\mathrm{PC}$ assemblage margins host all three plagioclase occurrences as described above; however, phenocrysts are smaller and not as obviously zoned or included. Spherulitic/variolitic plagioclase is more common than in the PCO assemblage. In contrast, the P assemblage margins have a hiatal texture with phenocrysts and glomerocrysts of

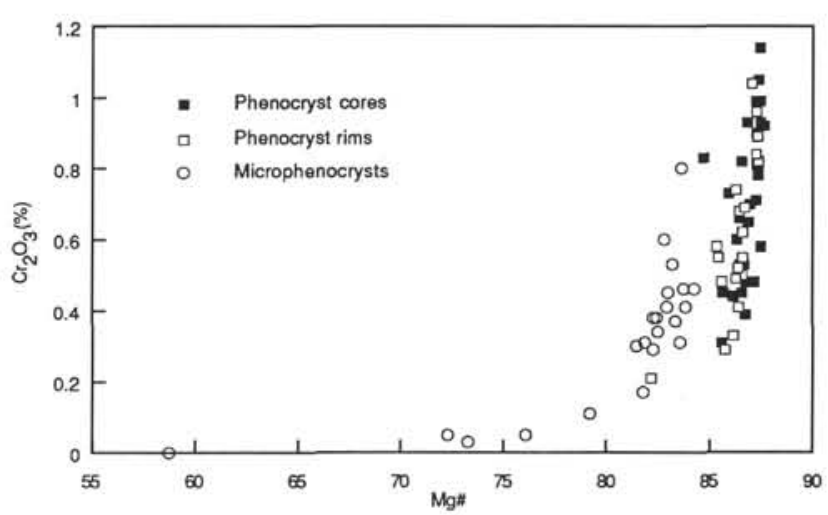

Figure 2. $\mathrm{Cr}_{2} \mathrm{O}_{3}$ contents of clinopyroxene phenocrysts and microphenocrysts plotted against $\mathrm{Mg} \#(100[\mathrm{Mg} / \mathrm{Mg}+\mathrm{Fe}])$. Microphenocrysts include quench crystals and spherulites.

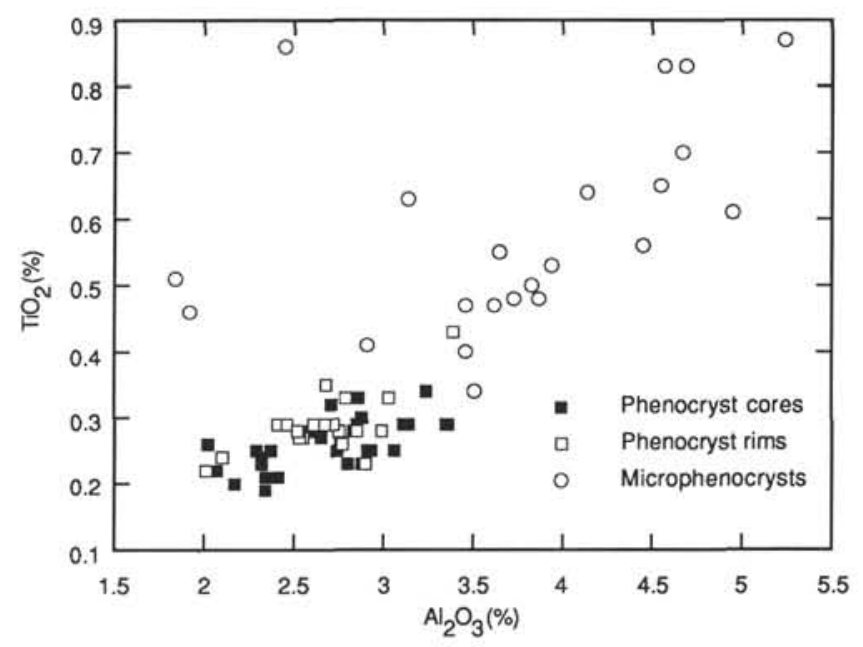

Figure $3 . \mathrm{TiO}_{2} \mathrm{vs} . \mathrm{Al}_{2} \mathrm{O}_{3}$ for clinopyroxene phenocrysts and microphenocrysts. Phenocrysts have lower $\mathrm{TiO}_{2}$ and $\mathrm{Al}_{2} \mathrm{O}_{3}$ contents than the microphenocrysts.

euhedral to anhedral plagioclase, $>0.1 \mathrm{~mm}$ length and $0.02 \mathrm{~mm}$ width, and skeletal microphenocrysts of $<0.1 \mathrm{~mm}$ length and $\sim 0.005 \mathrm{~mm}$ width.The phenocrysts may have quench overgrowths and may host rare inclusions of cryptocrystalline groundmass. The two microdikes host subhedral plagioclase laths, from 0.04 to $0.3 \mathrm{~mm}$ in length, and glomerocrysts but lack microphenocrysts or spherulitic plagioclase.

Plagioclase in the microdikes, PCO- and P-phyric margins (Tables 5 and 6 , and summarized in Table 7) has compositions ranging from $\mathrm{An}_{43}$ to $\mathrm{An}_{89}$, dominantly $\mathrm{An}_{70-86}$, consistent with previous analyses from the Hole 504B sheeted dikes (Kempton et al., 1985; Kusakabe et al., 1989) although not as calcic ( $\mathrm{An}_{94.5}$ maximum) as some phenocrysts from the pillow lava sequence (Natland et al., 1983) or the 
Table 4. Representative clinopyroxene compositions; PCO-phyric chilled margins from Leg 140, Hole 504B.

\begin{tabular}{|c|c|c|c|c|c|c|c|c|c|c|c|}
\hline \multirow[b]{2}{*}{ Analysis } & \multicolumn{4}{|c|}{$195 \mathrm{R}-1,7-10 \mathrm{~cm}$} & \multicolumn{7}{|c|}{$222 \mathrm{R}-1,0-4 \mathrm{~cm}$} \\
\hline & 1 & 2 & 3 & 4 & 5 & 6 & 7 & 8 & 9 & 10 & 11 \\
\hline $\mathrm{SiO}_{2}$ & 53.15 & 52.45 & 50.69 & 50.27 & 52.32 & 52.37 & 51.91 & 51.99 & 53.02 & 50.48 & 51.38 \\
\hline $\mathrm{TiO}_{2}^{2}$ & 0.21 & 0.33 & 0.83 & 0.83 & 0.30 & 0.33 & 0.25 & 0.28 & 0.41 & 0.64 & 0.51 \\
\hline $\mathrm{Al}_{2} \mathrm{O}_{3}$ & 2.41 & 3.03 & 4.69 & 4.57 & 2.88 & 2.79 & 2.91 & 2.99 & 2.91 & 4.14 & 1.84 \\
\hline $\mathrm{Cr}_{2} \mathrm{O}_{3}^{3}$ & 0.73 & 0.55 & 0.17 & 0.11 & 0.66 & 0.69 & 1.14 & 1.04 & 0.41 & 0.38 & 0.05 \\
\hline $\mathrm{FeO} *$ & 5.67 & 5.43 & 6.62 & 7.43 & 5.21 & 5.02 & 4.65 & 4.71 & 6.76 & 6.99 & 11.25 \\
\hline $\mathrm{MnO}$ & 0.26 & 0.22 & 0.24 & 0,15 & 0.23 & 0.14 & 0.24 & 0.17 & 0.18 & 0.19 & 0.42 \\
\hline $\mathrm{MgO}$ & 19.4 & 17.85 & 16.69 & 15.88 & 18.63 & 18.34 & 18.12 & 17.74 & 19.69 & 17.08 & 16.48 \\
\hline $\mathrm{CaO}$ & 18.03 & 19.78 & 19.96 & 19.86 & 19.14 & 20.01 & 20.2 & 21.19 & 16.62 & 18.42 & 17.2 \\
\hline $\mathrm{Na}_{2} \mathrm{O}$ & 0.17 & 0.18 & 0.20 & 0.18 & 0.19 & 0.21 & 0.19 & 0.21 & 0.19 & 0.20 & 0.23 \\
\hline $\mathrm{K}_{2} \mathrm{O}$ & 0.01 & 0.00 & 0.00 & 0.00 & 0.00 & 0.00 & 0.00 & 0.00 & 0.01 & 0.02 & 0.00 \\
\hline Total & 100.04 & 99.82 & 100.07 & 99.28 & 99.55 & 99.91 & 99.61 & 100.34 & 100.19 & 98.54 & 99.36 \\
\hline \multicolumn{12}{|c|}{ Cations calculated on the basis of 6 oxygens } \\
\hline $\mathrm{Si}$ & 1.931 & 1.918 & 1.862 & 1.868 & 1.914 & 1.912 & 1.903 & 1.898 & 1.923 & 1.874 & 1.929 \\
\hline $\mathrm{Al}$ & 0.103 & 0.131 & 0.203 & 0.200 & 0.124 & 0.12 & 0.126 & 0.129 & 0.124 & 0.181 & 0.082 \\
\hline $\mathrm{Fe}^{2+}$ & 0.172 & 0.166 & 0.203 & 0.231 & 0.160 & 0.153 & 0.143 & 0.144 & 0.205 & 0.217 & 0.353 \\
\hline $\mathrm{Mg}$ & 1.051 & 0.973 & 0.914 & 0.880 & 1.016 & 0.999 & 0.990 & 0.965 & 1.064 & 1.019 & 0.922 \\
\hline $\mathrm{Ca}$ & 0.702 & 0.775 & 0.786 & 0.791 & 0.750 & 0.783 & 0.793 & 0.829 & 0.646 & 0.679 & 0.692 \\
\hline $\mathrm{Na}$ & 0.012 & 0.013 & 0.014 & 0.013 & 0.013 & 0.015 & 0.014 & 0.015 & 0.014 & 0.015 & 0.017 \\
\hline K & 0.000 & 0.000 & 0.000 & 0.000 & 0.000 & 0.000 & 0.000 & 0.000 & 0.001 & 0.001 & 0.000 \\
\hline $\mathrm{Ti}$ & 0.006 & 0.009 & 0.023 & 0.023 & 0.008 & 0.009 & 0.007 & 0.008 & 0.011 & 0.018 & 0.014 \\
\hline Mn & 0.008 & 0.007 & 0.007 & 0.005 & 0.007 & 0.004 & 0.008 & 0.005 & 0.006 & 0.006 & 0.013 \\
\hline $\mathrm{Cr}$ & 0.021 & 0.016 & 0.005 & 0.003 & 0.019 & 0.020 & 0.033 & 0.030 & 0.012 & 0.011 & 0.001 \\
\hline Total & 4.007 & 4.006 & 4.018 & 4.014 & 4.012 & 4.016 & 4.017 & 4.023 & 4.005 & 4.020 & 4.024 \\
\hline En & 54.6 & 50.8 & 48.0 & 46.3 & 52.7 & 51.6 & 51.4 & 49.8 & 55.6 & 53.2 & 46.9 \\
\hline Fs & 9.0 & 8.7 & 10.7 & 12.1 & 8.3 & 7.9 & 7.4 & 7.4 & 10.7 & 11.3 & 18.0 \\
\hline Wo & 36.4 & 40.5 & 41.3 & 41.6 & 39.0 & 40.5 & 41.2 & 42.8 & 33.7 & 35.5 & 35.1 \\
\hline Mg\# & 85.9 & 85.4 & 81.8 & 79.2 & 86.4 & 86.7 & 87.4 & 87.0 & 83.8 & 82.5 & 72.3 \\
\hline
\end{tabular}

Notes: Analyses: 1 = core of twinned, $0.7 \times 0.4 \mathrm{~mm}$ euhedral phenocryst; $2=$ rim of phenocryst in analysis $1 ; 3=$ subhedral microphenocryst; $4=0.1 \times 0.04 \mathrm{~mm}$ subhedral grain in spherulite. $5=$ core of euhedral to weakly embayed, $0.75 \times$ $0.55 \mathrm{~mm}$ phenocryst; $6=$ rim of phenocryst in analysis $5 ; 7=$ core of embayed phenocryst, $0.75 \times 0.3 \mathrm{~mm} ; 8=\mathrm{rim}$ of phenocryst in analysis $7 ; 9=$ subhedral grain in spherulite with plagioclase, $0.04 \times 0.02 \mathrm{~mm} ; 10=$ subhedral grain in holocrystalline groundmass, $0.015 \times 0.015 \mathrm{~mm} ; 11$ = rounded anhedral microphenocryst, $0.08 \times 0.1 \mathrm{~mm}$. *All Fe as $\mathrm{FeO}$.

interior of some dikes recovered on Leg 140 (Johnson et al., this volume). The compositional range of microphenocrysts and phenocrysts overlaps slightly, and they are therefore differentiated only on the basis of morphology (Fig. 4). Zoning in plagioclase has not been investigated in detail, but core and rim analyses indicate phenocrysts from a single sample may be both normally and reversely zoned.

Variations in plagioclase $\mathrm{Mg \#}$ and $\mathrm{MgO}$ content with decreasing anorthite (Fig. 4 and 5) are similar to those described previously (Kusukabe, et al., 1989; Ishizuka, 1989).

\section{Whole-rock geochemistry}

Major and trace element analyses of selected chilled margins are given in Table 8 . The analyzed margins are characterized by moderate to high $\mathrm{CaO} / \mathrm{Na}_{2} \mathrm{O}$ values, 5.5-6.6, low $\mathrm{TiO}_{2}$ and $\mathrm{K}_{2} \mathrm{O},<1.05 \%$ and $<0.02 \%$, respectively, and on the basis of $\mathrm{Zr}$ and $\mathrm{Nb}$ contents fall in the field of group D basalts of Autio and Rhodes (1983). Group D basalts comprise approximately $98 \%$ of the analyzed basalts and diabases from Hole 504B. They are characterized by abnormally depleted incompatible element contents, but with incompatible element ratios are similar to those of normal mid-ocean ridge basalt (N-MORB). The geochemical signature of these samples is discussed in some detail by the Shipboard Scientific Party (1992).

Chondrite-normalized rare-earth element (REE) plots (Fig. 6) show light rare-earth element (LREE) depleted patterns typical of the majority of extrusive and dike samples from Hole 504B (Shimizu et al., 1989; Kempton, et al., 1985) with stronger LREE depletion than the typical N-MORB of Sun and McDonough (1989). The reason for the low Ce contents in Samples 140-504B-222R-1, 0-4 cm, and 140-504B-203R-1, 4-7 cm, is unclear, but La and HREE abundances are consistent with the other analyses. The $(\mathrm{La} / \mathrm{Sm})_{\mathrm{N}}$ values for these samples range from 0.29 to 0.33 , lower than typical N-MORB values of 0.4-0.7, and are similar to the results of Tual et al. (1985) and Shimizu et al. (1989).

\section{Summary}

The chilled margins recovered during Leg 140 have gross morphological characteristics (i.e., lack of glass and steeply dipping contacts), similar to the upper dike sequence. Phenocryst phases and assemblages are texturally and chemically similar to those reported from the pillow lava sequence (Natland et al., 1983). The smaller range of compositions recorded here is more likely a result of restricted sampling than actual variation with depth.

Major differences in mineralogy between the chilled margins and pillow lavas include the scarcity of spinel and its occurrence only as inclusions in the chilled margins, and the presence of plagioclase as the only phenocryst phase in many chilled margins. A contrast between the chilled margins and interiors of the dikes is the absence of glomerocrysts containing both olivine and clinopyroxene in the chilled margins, a situation also described from the pillow lavas by Natland et al. (1983).

Whole-rock geochemical patterns are entirely consistent with previous results from higher levels in the drill hole, and confirm the depleted nature of these rocks.

\section{ACKNOWLEDGMENTS}

This work was completed while in receipt of an Australian postgraduate research award at the University of Tasmania. I am indebted to Dr. A.J. Crawford for discussions and support, and Wis Jablonski and Phil Robinson for help with the analytical work. 
Table 5. Representative plagioclase compositions; PCO-phyric chilled margins, Hole 504B, Leg 140.

\begin{tabular}{|c|c|c|c|c|c|c|c|c|c|c|c|c|}
\hline \multirow[b]{2}{*}{ Analysis } & \multicolumn{5}{|c|}{$195 \mathrm{R}-1,7-10 \mathrm{~cm}$} & \multicolumn{7}{|c|}{$222 \mathrm{R}-1,0-4 \mathrm{~cm}$} \\
\hline & 1 & 2 & 3 & 4 & 5 & 6 & 7 & 8 & 9 & 10 & 11 & 12 \\
\hline $\mathrm{SiO}_{2}$ & 47.44 & 47.23 & 47.47 & 47.58 & 50.80 & 46.58 & 47.89 & 46.43 & 46.22 & 57.91 & 47.70 & 50.66 \\
\hline $\mathrm{TiO}_{2}^{2}$ & 0.01 & 0.01 & 0.00 & 0.06 & 0.02 & 0.03 & 0.02 & 0.02 & 0.01 & 0.00 & 0.03 & 0.03 \\
\hline $\mathrm{Al}_{2} \mathrm{O}_{3}$ & 32.71 & 32.65 & 32.64 & 32.08 & 29.93 & 33.00 & 31.78 & 32.77 & 32.78 & 25.88 & 32.15 & 30.22 \\
\hline $\mathrm{Cr}_{2} \mathrm{O}_{3}$ & 0.03 & 0.03 & 0.03 & 0.01 & 0.00 & 0.02 & 0.02 & 0.00 & 0.02 & 0.00 & 0.05 & 0.05 \\
\hline $\mathrm{FeO}^{*}$ & 0.51 & 0.50 & 0.58 & 0.58 & 0.81 & 0.45 & 0.53 & 0.46 & 0.46 & 0.49 & 0.65 & 0.72 \\
\hline $\mathrm{MnO}$ & 0.00 & 0.00 & 0.00 & 0.03 & 0.00 & 0.00 & 0.01 & 0.06 & 0.00 & 0.00 & 0.04 & 0.02 \\
\hline $\mathrm{MgO}$ & 0.24 & 0.20 & 0.24 & 0.25 & 0.32 & 0.22 & 0.29 & 0.19 & 0.20 & 0.16 & 0.27 & 0.33 \\
\hline $\mathrm{CaO}$ & 17.41 & 17.37 & 17.33 & 16.68 & 14.81 & 17.36 & 16.62 & 17.61 & 17.66 & 9.09 & 16.84 & 14.76 \\
\hline $\mathrm{SrO}$ & 0.17 & 0.19 & 0.20 & 0.16 & 0.19 & 0.16 & 0.19 & 0.18 & 0.14 & 0.21 & 0.16 & 0.17 \\
\hline $\mathrm{BaO}$ & 0.00 & 0.05 & 0.00 & 0.06 & 0.00 & 0.03 & 0.00 & 0.00 & 0.04 & 0.06 & 0.00 & 0.02 \\
\hline $\mathrm{Na}_{2} \mathrm{O}$ & 1.65 & 1.64 & 1.71 & 1.89 & 3.02 & 1.44 & 1.98 & 1.39 & 1.32 & 6.54 & 1.93 & 3.08 \\
\hline $\mathrm{K}_{2} \mathrm{O}$ & 0.01 & 0.01 & 0.00 & 0.01 & 0.01 & 0.01 & 0.01 & 0.01 & 0.00 & 0.04 & 0.01 & 0.00 \\
\hline Total & 100.19 & 99.88 & 100.20 & 99.38 & 99.92 & 99.30 & 99.35 & 99.13 & 98.86 & 100.37 & 99.82 & 100.06 \\
\hline
\end{tabular}

Cations calculated on the basis of 8 oxygens

\begin{tabular}{|c|c|c|c|c|c|c|c|c|c|c|c|c|}
\hline $\mathrm{Si}$ & 2.182 & 2.18 & 2.184 & 2.204 & 2.327 & 2.162 & 2.218 & 2.161 & 2.157 & 2.596 & 2.201 & 2.318 \\
\hline Al & 1.773 & 1.777 & 1.77 & 1.752 & 1.616 & 1.805 & 1.735 & 1.798 & 1.803 & 1.367 & 1.749 & 1.629 \\
\hline $\mathrm{Fe}$ & 0.020 & 0.019 & 0.022 & 0.023 & 0.031 & 0.017 & 0.021 & 0.018 & 0.018 & 0.018 & 0.025 & 0.028 \\
\hline $\mathrm{Mg}$ & 0.016 & 0.014 & 0.017 & 0.017 & 0.022 & 0.015 & 0.020 & 0.013 & 0.014 & 0.011 & 0.019 & 0.023 \\
\hline $\mathrm{Ca}$ & 0.858 & 0.859 & 0.854 & 0.828 & 0.727 & 0.863 & 0.825 & 0.878 & 0.883 & 0.436 & 0.833 & 0.724 \\
\hline $\mathrm{Na}$ & 0.147 & 0.147 & 0.153 & 0.170 & 0.268 & 0.129 & 0.178 & 0.126 & 0.119 & 0.568 & 0.172 & 0.273 \\
\hline K & 0.001 & 0.001 & 0.000 & 0.000 & 0.001 & 0.000 & 0.001 & 0.001 & 0.000 & 0.002 & 0.000 & 0.000 \\
\hline $\mathrm{Ti}$ & 0.000 & 0.000 & 0.000 & 0.002 & 0.001 & 0.001 & 0.001 & 0.001 & 0.000 & 0.000 & 0.001 & 0.001 \\
\hline Mn & 0.000 & 0.000 & 0.000 & 0.001 & 0.000 & 0.000 & 0.000 & 0.002 & 0.000 & 0.000 & 0.001 & 0.001 \\
\hline $\mathrm{Cr}$ & 0.001 & 0.001 & 0.001 & 0.000 & 0.000 & 0.001 & 0.001 & 0.000 & 0.001 & 0.000 & 0.002 & 0.002 \\
\hline $\mathrm{Sr}$ & 0.005 & 0.005 & 0.005 & 0.004 & 0.005 & 0.004 & 0.005 & 0.005 & 0.004 & 0.005 & 0.004 & 0.005 \\
\hline $\mathrm{Ba}$ & 0.000 & 0.001 & 0.000 & 0.001 & 0.000 & 0.001 & 0.000 & 0.000 & 0.001 & 0.001 & 0.000 & 0.000 \\
\hline Total & 5.004 & 5.004 & 5.007 & 5.003 & 4.998 & 4.999 & 5.003 & 5.003 & 5.000 & 5.006 & 5.008 & 5.002 \\
\hline An & 85.3 & 85.4 & 84.8 & 82.9 & 73.0 & 86.9 & 82.2 & 87.4 & 88.1 & 43.4 & 82.8 & 72.6 \\
\hline $\mathrm{Ab}$ & 14.7 & 14.6 & 15.2 & 17.0 & 26.9 & 13.0 & 17.7 & 12.5 & 11.9 & 56.4 & 17.2 & 27.4 \\
\hline Or & 0.0 & 0.0 & 0.0 & 0.1 & 0.1 & 0.1 & 0.1 & 0.1 & 0.0 & 0.2 & 0.0 & 0.0 \\
\hline $\mathrm{Mg} \#$ & 45.5 & 42.0 & 42.4 & 43.1 & 41.2 & 46.8 & 49.4 & 42.4 & 43.1 & 37.4 & 42.7 & 45.2 \\
\hline
\end{tabular}

Notes: Analyses: $1=$ core of subhedral phenocryst, $0.25 \times 0.65 \mathrm{~mm}$, in glomerocryst; 2 = rim of phenocryst in analysis $1 ; 3=$ subhedral phenocryst, $0.12 \times 0.04 \mathrm{~mm}$, included in pyroxene; $4=$ subhedral phenocryst, $0.17 \times 0.06 \mathrm{~mm}$, in glomerocryst; $5=$ skeletal microphenocryst, $0.04 \times 0.01 \mathrm{~mm}$, in holocrystalline groundmass; $6=$ core of subhedral phenocryst, $0.3 \times 0.1 \mathrm{~mm}$, in glomerocryst; $7=$ rim of phenocryst in analysis $6 ; 8=$ core of subhedral inclusion in pyroxene, $0.56 \times 0.14 \mathrm{~mm} ; 9=$ rim of phenocryst in analysis $8 ; 10=$ skeletal microphenocryst, $0.04 \times 0.01 \mathrm{~mm}$, in cryptocrystalline groundmass; $11=$ euhedral microphenocryst, $0.025 \times 0.013 \mathrm{~mm}$, in holocrystalline groundmass; $12=$ skeletal microphenocryst, $0.035 \times 0.01 \mathrm{~mm}$, in holocrystalline groundmass. *All $\mathrm{Fe}$ as $\mathrm{FeO}$.

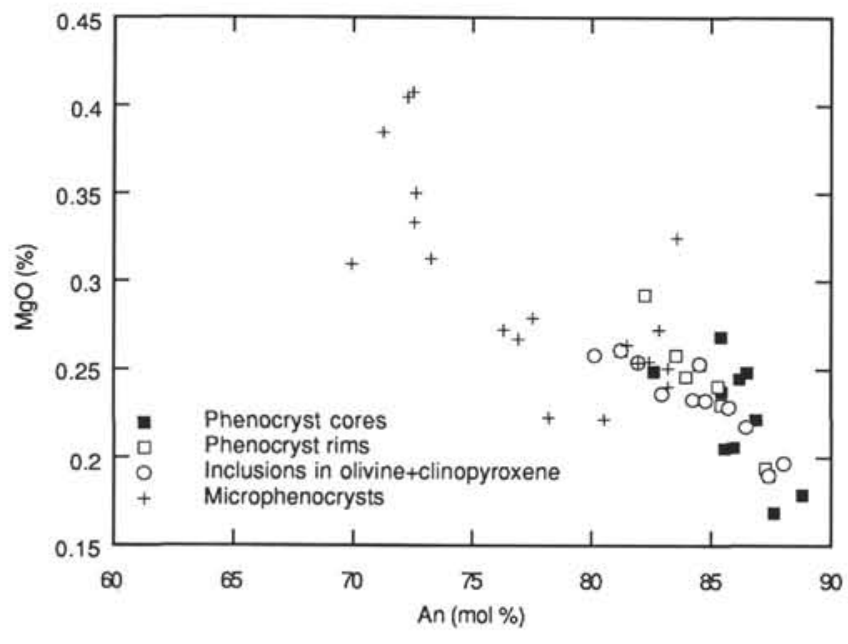

Figure 4. $\mathrm{MgO}$ vs. An $(100[\mathrm{Ca} / \mathrm{Ca}+\mathrm{Na}+\mathrm{K}])$ content of plagioclase phenocrysts from Sample 140-504B-222R-1, 0-4 cm. The trend of increasing $\mathrm{MgO}$ with decreasing An content, above $\mathrm{An}_{70}$, is consistent with previous studies (Kempton, 1985; Sato, 1989).

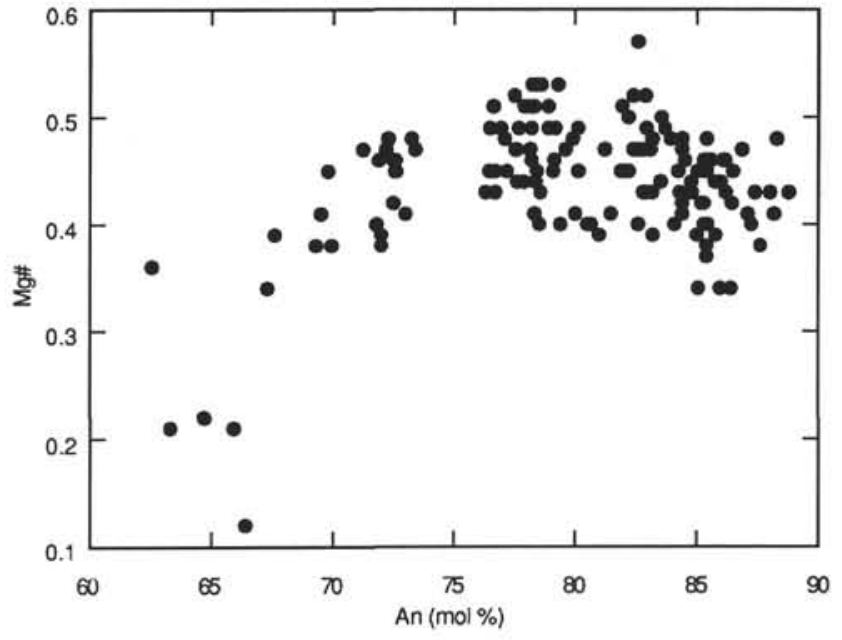

Figure 5. $\mathrm{Mg} \#(100[\mathrm{Mg} / \mathrm{Mg}+\mathrm{Fe}])$ vs. An $(100[\mathrm{Ca} / \mathrm{Ca}+\mathrm{Na}+\mathrm{K}])$ contents for plagioclase phenocrysts and microphenocrysts from Leg 140 chilled margins. Two microphenocrysts with An contents of $<60$ are not plotted. 
Table 6. Representative plagioclase compositions; plagioclase-phyric chilled margins and microdikes, Hole 504B, Leg 140 .

\begin{tabular}{|c|c|c|c|c|c|c|c|c|c|c|c|c|c|}
\hline Analysis & 1 & 2 & 3 & 4 & 5 & 6 & 7 & 8 & 9 & 10 & 11 & 12 & 13 \\
\hline $\mathrm{SiO}_{2}$ & 48.31 & 47.71 & 47.65 & 48.23 & 47.03 & 49.09 & 48.9 & 49.07 & 49.27 & 51.3 & 46.3 & 46.92 & 47.13 \\
\hline $\mathrm{TiO}_{2}^{2}$ & 0.00 & 0.01 & 0.02 & 0.07 & 0.00 & 0.03 & 0.00 & 0.06 & 0.03 & 0.04 & 0.00 & 0.00 & 0.00 \\
\hline $\mathrm{Al}_{2} \mathrm{O}_{3}$ & 31.44 & 32.07 & 31.84 & 31.13 & 32.89 & 31.36 & 31.25 & 31.18 & 31.07 & 29.14 & 32.56 & 30.01 & 32.15 \\
\hline $\mathrm{Cr}_{2}^{2} \mathrm{O}_{3}$ & 0.00 & $\mathrm{n} / \mathrm{a}$ & $\mathrm{n} / \mathrm{a}$ & $\mathrm{n} / \mathrm{a}$ & 0.01 & 0.00 & 0.00 & 0.00 & 0.00 & 0.00 & 0.05 & 0.08 & 0.05 \\
\hline $\mathrm{FeO} *$ & 0.69 & 0.29 & 0.25 & 0.49 & 0.48 & 0.46 & 0.58 & 0.45 & 0.58 & 1.10 & 0.53 & 1.78 & 0.7 \\
\hline $\mathrm{MnO}$ & 0.00 & 0.00 & 0.04 & 0.00 & 0.00 & 0.07 & 0.00 & 0.00 & 0.00 & 0.00 & 0.07 & 0.05 & 0.00 \\
\hline $\mathrm{MgO}$ & 0.25 & 0.39 & 0.43 & 0.85 & 0.21 & 0.25 & 0.21 & 0.29 & 0.26 & 0.42 & 0.22 & 1.15 & 0.25 \\
\hline $\mathrm{CaO}$ & 16.23 & 16.75 & 17.00 & 16.35 & 16.97 & 15.76 & 16.18 & 15.81 & 15.56 & 14.05 & 17.64 & 16.68 & 16.97 \\
\hline $\mathrm{SrO}$ & 0.18 & $\mathrm{n} / \mathrm{a}$ & $\mathrm{n} / \mathrm{a}$ & $\mathrm{n} / \mathrm{a}$ & 0.17 & 0.17 & 0.17 & 0.18 & 0.18 & 0.18 & 0.18 & 0.2 & 0.17 \\
\hline $\mathrm{BaO}$ & 0.09 & $\mathrm{n} / \mathrm{a}$ & $\mathrm{n} / \mathrm{a}$ & $\mathrm{n} / \mathrm{a}$ & 0.00 & 0.00 & 0.01 & 0.03 & 0.03 & 0.00 & 0.07 & 0.03 & 0.04 \\
\hline $\mathrm{Na}_{2} \mathrm{O}$ & 2.31 & 1.94 & 2.01 & 2.38 & 1.65 & 2.41 & 2.43 & 2.39 & 2.53 & 3.38 & 1.55 & 1.57 & 1.88 \\
\hline $\mathrm{K}_{2} \mathrm{O}$ & 0.01 & 0.00 & 0.00 & 0.04 & 0.00 & 0.02 & 0.02 & 0.01 & 0.00 & 0.04 & 0.00 & 0.02 & 0.02 \\
\hline Total & 99.51 & 99.16 & 99.23 & 99.55 & 99.42 & 99.63 & 99.76 & 99.47 & 99.53 & 99.65 & 99.17 & 98.49 & 99.35 \\
\hline \multicolumn{14}{|c|}{ Cations calculated on the basis of 8 oxygens } \\
\hline $\mathrm{Si}$ & 2.235 & 2.21 & 2.209 & 2.232 & 2.177 & 2.259 & 2.253 & 2.262 & 2.27 & 2.356 & 2.159 & 2.211 & 2.189 \\
\hline Al & 1.714 & 1.751 & 1.740 & 1.698 & 1.795 & 1.701 & 1.697 & 1.694 & 1.687 & 1.577 & 1.789 & 1.667 & 1.76 \\
\hline $\mathrm{Fe}$ & 0.027 & 0.015 & 0.016 & 0.033 & 0.018 & 0.018 & 0.022 & 0.017 & 0.023 & 0.042 & 0.021 & 0.07 & 0.027 \\
\hline $\mathrm{Mg}$ & 0.017 & 0.020 & 0.018 & 0.034 & 0.015 & 0.017 & 0.015 & 0.02 & 0.018 & 0.029 & 0.015 & 0.081 & 0.017 \\
\hline $\mathrm{Ca}$ & 0.804 & 0.831 & 0.845 & 0.811 & 0.841 & 0.777 & 0.799 & 0.781 & 0.768 & 0.691 & 0.881 & 0.842 & 0.845 \\
\hline $\mathrm{Na}$ & 0.207 & 0.174 & 0.181 & 0.214 & 0.148 & 0.215 & 0.217 & 0.214 & 0.226 & 0.301 & 0.140 & 0.143 & 0.169 \\
\hline K & 0.000 & 0.000 & 0.000 & 0.002 & 0.000 & 0.001 & 0.001 & 0.001 & 0.000 & 0.002 & 0.000 & 0.001 & 0.001 \\
\hline $\mathrm{Ti}$ & 0.000 & 0.000 & 0.001 & 0.003 & 0.000 & 0.001 & 0.000 & 0.002 & 0.001 & 0.001 & 0.000 & 0.000 & 0.000 \\
\hline $\mathrm{Mn}$ & 0.000 & 0.000 & 0.001 & 0.000 & 0.000 & 0.003 & 0.000 & 0.000 & 0.000 & 0.000 & 0.003 & 0.002 & 0.000 \\
\hline $\mathrm{Cr}$ & 0.000 & $\mathrm{n} / \mathrm{a}$ & $\mathrm{n} / \mathrm{a}$ & $\mathrm{n} / \mathrm{a}$ & 0.000 & 0.000 & 0.000 & 0.000 & 0.000 & 0.000 & 0.002 & 0.003 & 0.002 \\
\hline $\mathrm{Sr}$ & 0.005 & $\mathrm{n} / \mathrm{a}$ & $\mathrm{n} / \mathrm{a}$ & $\mathrm{n} / \mathrm{a}$ & 0.005 & 0.005 & 0.005 & 0.005 & 0.005 & 0.005 & 0.005 & 0.006 & 0.005 \\
\hline $\mathrm{Ba}$ & 0.002 & $\mathrm{n} / \mathrm{a}$ & $\mathrm{n} / \mathrm{a}$ & $\mathrm{n} / \mathrm{a}$ & 0.000 & 0.000 & 0.000 & 0.001 & 0.001 & 0.000 & 0.001 & 0.001 & 0.001 \\
\hline Total & 5.012 & 5.002 & 5.011 & 5.025 & 5.000 & 4.997 & 5.008 & 4.996 & 4.998 & 5.005 & 5.016 & 5.027 & 5.015 \\
\hline An & 79.5 & 82.6 & 82.4 & 78.9 & 85.0 & 78.2 & 78.5 & 78.5 & 77.2 & 69.5 & 86.3 & 85.4 & 83.3 \\
\hline $\mathrm{Ab}$ & 20.5 & 17.4 & 17.6 & 20.8 & 15.0 & 21.7 & 21.4 & 21.5 & 22.8 & 30.3 & 13.7 & 14.5 & 16.6 \\
\hline Or & 0.0 & 0.0 & 0.0 & 0.3 & 0.0 & 0.1 & 0.1 & 0.0 & 0.0 & 0.2 & 0.0 & 0.1 & 0.1 \\
\hline Mg\# & 39.4 & 56.7 & 51.6 & 50.6 & 44.4 & 49.0 & 39.5 & 53.0 & 44.5 & 41.0 & 42.5 & 53.7 & 38.5 \\
\hline
\end{tabular}

Notes: Analyses: $1=201 \mathrm{R}-1,14-17 \mathrm{~cm}$, core of euhdral lath, $0.3 \times 0.06 \mathrm{~mm} ; 2=203 \mathrm{R}-1,33-36 \mathrm{~cm}$, core of euhedral lath, $1.05 \times 0.18$ $\mathrm{mm}$, with cryptocrystalline inclusions; $3=$ rim of phenocryst in analysis $2 ; 4=203 \mathrm{R}-1,33-36 \mathrm{~cm}$, core of euhedral lath, $0.2 \times 0.02$ $\mathrm{mm} ; 5=208 \mathrm{R}-1,30-33 \mathrm{~cm}$, core of subhedral phenocryst, $0.34 \times 0.1 \mathrm{~mm} ; 6=$ rim of phenocryst in analysis $5 ; 7=208 \mathrm{R}-1,30-33 \mathrm{~cm}$, core of microphenocryst, $0.055 \times 0.005 \mathrm{~mm}$, with dendritic overgrowths; $8=208 \mathrm{R}-1,30-33 \mathrm{~cm}$, core of subhedral phenocryst, 0.011 $\times 0.015 \mathrm{~mm} ; 9=$ rim of phenocryst in analysis $8 ; 10=208 \mathrm{R}-1,30-33 \mathrm{~cm}$, skeletal microphenocryst, $0.005 \times 0.06 \mathrm{~mm} ; 11=213 \mathrm{R}-1$, $32-34 \mathrm{~cm}$, core of subhedral phenocryst, $0.15 \times 0.03 \mathrm{~mm} ; 12=$ rim of phenocryst in analysis $11 ; 13=213 \mathrm{R}-1,32-34 \mathrm{~cm}$, core of subhedral phenocryst, $0.04 \times 0.02 \mathrm{~mm}$. n/a $=$ element not analyzed. *All $\mathrm{Fe}$ as $\mathrm{FeO}$.

\section{REFERENCES*}

Adamson, A.C., 1985. Basement lithostratigraphy, Deep Sea Drilling Project Hole 504B. In Anderson, R.N., Honnorez, J., Becker, K., et al., Init. Repts. DSDP, 83: Washington (U.S. Govt. Printing Office), 121-127.

Autio, L.K., and Rhodes, J.M., 1983. Costa Rica Rift Zone basalts: geochemical and experimental data from a possible example of multistage melting. In Cann, J.R., Langseth, M.G., Honnorez, J., Von Herzen, R.P., White, S.M., et al., Init. Repts. DSDP, 69: Washington (U.S. Govt. Printing Office), 729-745.

Coish, R.A., and Taylor, L.A., 1979. The effects of cooling rate on texture and pyroxene chemistry in DSDP Leg 34 basalt: a microprobe study. Earth Planet. Sci. Lett., 42:389-398.

Gamble, R.P., and Taylor, L.A., 1980. Crystal/liquid partitioning in augite: effects of cooling rate. Earth Planet. Sci. Lett., 47:21-33.

Grove, T.L., and Bryan, W.B., 1983. Fractionation of pyroxene-phyric MORB at low pressure: an experimental study. Contrib. Mineral. Petrol., 84:293309.

Ishizuka, H., 1989. Mineral paragenesis of altered basalts from Hole 504B, ODP Leg 111. In Becker, K., Sakai, H., et al., Proc. ODP, Sci. Results, 111: College Station, TX (Ocean Drilling Program), 61-76.

Kempton, P.D., 1985. An interpretation of contrasting nucleation and growth histories from the petrographic analysis of pillow and dike chilled margins, Hole 504B, Deep Sea Drilling Project, Leg 83. In Anderson, R.N., Honnorez, J., Becker, K., et al., Init. Repts. DSDP, 83: Washington (U.S. Govt. Printing Office), 165-181.

\footnotetext{
Abbreviations for names of organizations and publications in ODP reference lists follow the style given in Chemical Abstracts Service Source Index (published by American Chemical Society).
}

Kempton, P.D., Autio, L.K., Rhodes, J.M., Holdaway, M.J., Dungan, M.A., and Johnson, P., 1985. Petrology of basalts from Hole 504B, Deep Sea Drilling Project, Leg 83. In Anderson, R.N., Honnorez, J., Becker, K., et al., Init. Repts. DSDP, 83: Washington (U.S. Govt. Printing Office), 129-164.

Kusakabe, M., Shibata, T., Yamamoto, M., Mayeda, S., Kagami, H., Honma, H., Masuda, H., and Sakai, H., 1989. Petrology and isotope characteristics $(\mathrm{H}, \mathrm{O}, \mathrm{S}, \mathrm{Sr}$, and $\mathrm{Nd})$ of basalts from Ocean Drilling Program Hole 504B, Leg 111, Costa Rica Rift. In Becker, K., Sakai, H., et al., Proc. ODP, Sci. Results, 111: College Station, TX (Ocean Drilling Program), 47-60.

Morimoto, N., et al., 1989. Nomenclature of pyroxenes. Can. Mineral. 27:143-156.

Natland, J.H., Adamson, A.C., Laverne, C., Melson, W.G., and O'Hearn, T., 1983. A compositionally nearly steady-state magma chamber at the Costa Rica Rift: evidence from basalt glass and mineral data, Deep Sea Drilling Project Sites 501, 504, and 505. In Cann, J.R., Langseth, M.G., Honnorez, J., Von Herzen, R.P., White, S.M., et al., Init. Repts. DSDP, 69: Washington (U.S. Govt. Printing Office), 811-858.

Norrish, K., and Chappell, B., 1977. X-ray fluorescence spectrometry. In Zussman, J. (Ed.), Physical Methods in Determinative Mineralogy (2nd ed.): New York (Academic Press), 201-272.

Roeder, P.L., and Emslie, R.F., 1970. Olivine-liquid equilibrium. Contrib. Mineral. Petrol., 29:275-289.

Sato, H., 1989. Mg-Fe partitioning between plagioclase and liquid in basalts of Hole 504B, ODP Leg 111: a study of melting at $1 \mathrm{~atm}$. In Becker, K., Sakai, H., et al., Proc. ODP, Sci. Results, 111: College Station, TX (Ocean Drilling Program), 17-26.

Shimizu, H., Mori, K., and Masuda, A., 1989. REE, Ba, and Sr abundances and $\mathrm{Sr}, \mathrm{Nd}$, and Ce isotopic ratios in Hole 504B basalts, ODP Leg 111, Costa Rica Rift. In Becker, K., Sakai, H., et al., Proc. ODP, Sci. Results, 111: College Station, TX (Ocean Drilling Program), 77-83. 
Shipboard Scientific Party, 1988. Site 504: Costa Rica Rift. In Becker, K., Sakai, H., et al., Proc. ODP, Init. Repts., 111: College Station, TX (Ocean Drilling Program), 35-251.

1992. Site 504. In Dick, H.J.B., Erzinger, J., Stokking, L.B., et al., Proc. ODP, Init. Repts., 140: College Station, TX (Ocean Drilling Program), 37-200.

Sun, S.-S., and McDonough, W.F., 1989. Chemical and isotopic systematics of oceanic basalts: implications for mantle composition and processes. In Saunders, A.D., and Norry, M.J. (Eds.), Magmatism in the Ocean Basins. Geol. Soc. Spec. Publ. London, 42:313-345.

Tual, E., Jahn, B.M., Bougault, H., and Joron, J.L., 1985. Geochemistry of basalts from Hole 504B, Leg 83, Costa Rica Rift. In Anderson, R.N., Honnorez, J., Becker, K., et al., Init. Repts. DSDP, 83: Washington (U.S. Govt. Printing Office), 201-214.

Ulmer, P., 1989. The dependence of the $\mathrm{Fe}^{2+}-\mathrm{Mg}$ cation-partitioning between olivine and basaltic liquid on pressure, temperature and composition: an experimental study to 30 kbars. Contrib. Mineral. Petrol., 101:261-273.

Date of initial receipt: 19 July 1993

Date of acceptance: 6 June 1994

Ms 137/140SR-009
Table 7. Summary of plagioclase anorthite contents for microdikes and PCO- and P-phyric chilled margins from Hole 504B, Leg 140.

\begin{tabular}{lccc}
\hline & PCO & P & Microdike \\
\hline Phenocryst-core & $80-89 *$ & $78-85$ & $79-86$ \\
Phenocryst-rim & $82-87$ & $77-82$ & $79-86$ \\
Inclusion in olivine & $84-87$ & - & - \\
Inclusion in pyroxene & $80-88$ & - & - \\
Microphenocryst & $43-83$ & $63-79$ & - \\
Spherulite & $73-74$ & - & - \\
\end{tabular}

Note: ${ }^{*} \mathrm{An}=\mathrm{Ca} /(\mathrm{Ca}+\mathrm{Na}+\mathrm{K})$
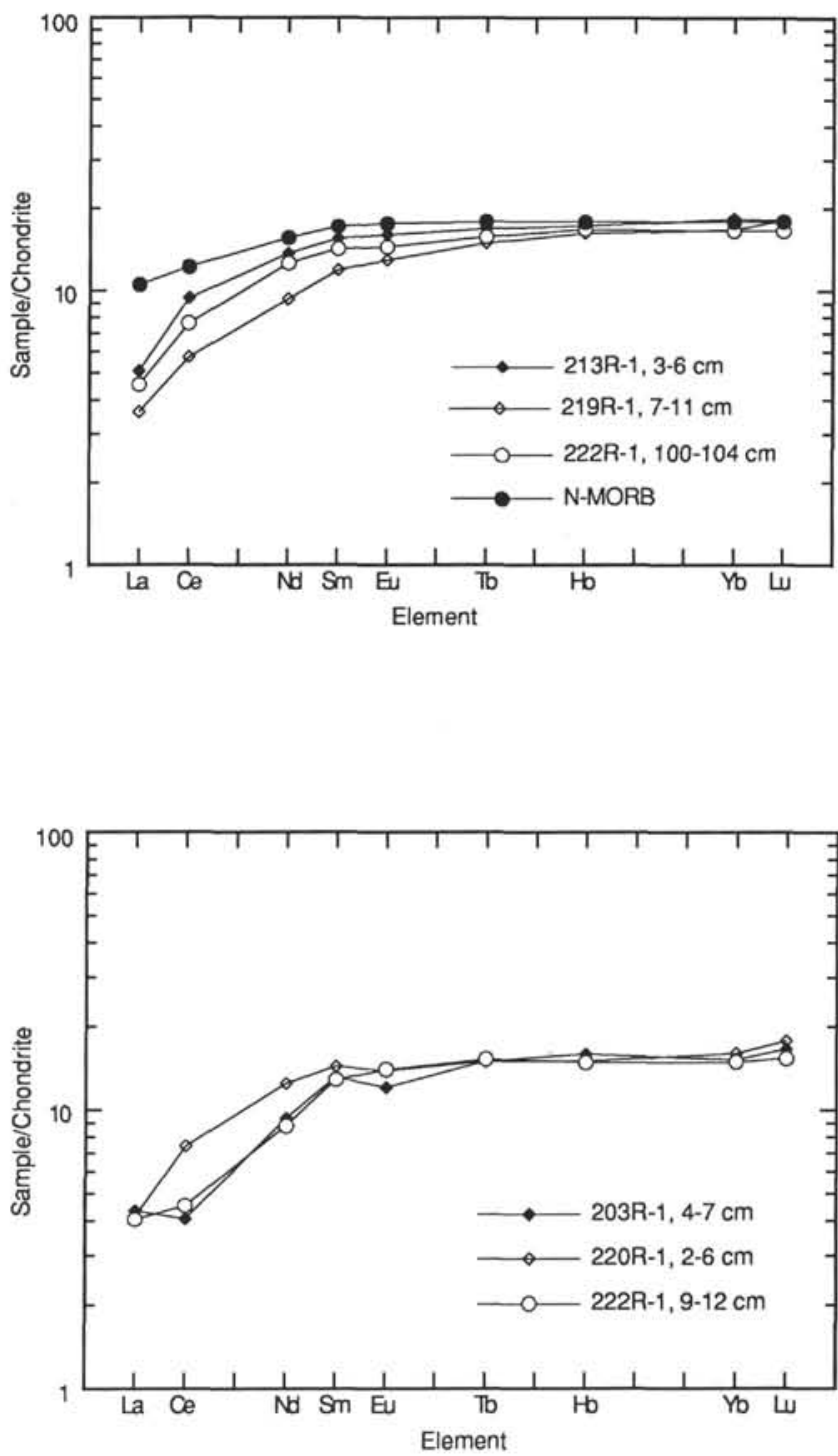

Figure 6. Chondrite-normalized REE patterns of selected chilled margins, Hole 504B, Leg 140. Normalizing factors are those of Sun and McDonough (1989). A typical N-MORB pattern (Sun and McDonough, 1989) is included for comparison. 
Table 8. Major and trace element compositions of chilled margins from Hole 504B, Leg 140.

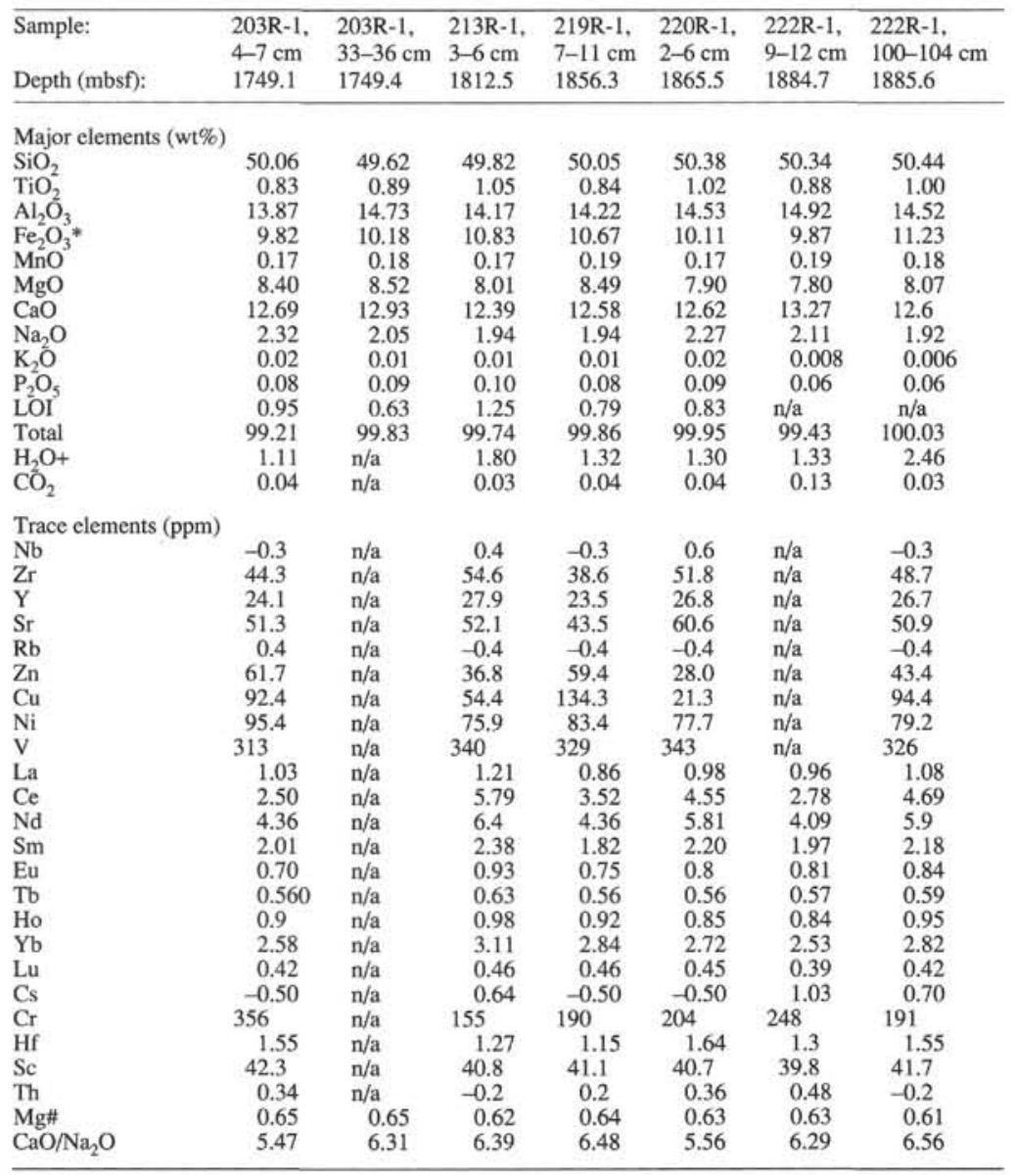

Notes: $\mathrm{n} / \mathrm{a}=$ not analyzed. $-0.3=$ below detection limit. Values for $\mathrm{H}_{2} \mathrm{O}, \mathrm{CO}_{2}, \mathrm{Nb}, \mathrm{Zr}, \mathrm{Y}, \mathrm{Sr}, \mathrm{Rb}, \mathrm{Zn}, \mathrm{Cu}, \mathrm{Ni}$, and $\mathrm{V}$ are from Shipboard Scientific Party (1992). $\mathrm{Mg} \#=(\mathrm{Mg} / \mathrm{Mg}+\mathrm{Fe}),{ }^{*} \mathrm{All} \mathrm{Fe}$ as $\mathrm{Fe}_{2} \mathrm{O}_{3}$. 